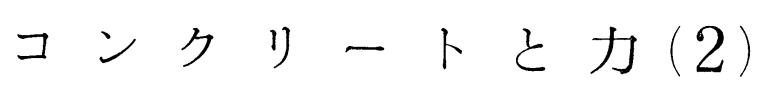

小阪 義 夫*

\section{1. 压縮強度}

コンクリートの場合, 単に強度といらと, ただちに圧 縮強度を思いうかい゙る人が多いと思う。圧縮強度は, そ れほどにコンクリートの強度特性の中でも重要視されて いる。これは，

（i）コンクリートは，鋼や木材などと違って，圧縮 強度にくらべると, 引張りや曲げの強度が極端に小 さく, そのため, 構造物はもっぱらコンクリートの 圧縮強度を活用するような使い方がなされている (この点, 鉄筋コンクリート構造は, 圧縮力をコン クリートに，引張力を鉄筋にそれぞれ負担させる巧 妙な複合構造である)。

（ii）引張りや曲げなどの強度と圧縮强度との間に は,おおよそ一定の関倸があるので, 圧縮強度が分か れば他の強度はある程度推測することができきる。

（iii）圧縮強度試験の方法は, 他の強度試験の方法に 比べると簡単である。 などが, その背景にあるからであろら。水セメント比 説や, セメント水比説などのコンクリートの強度論も, この圧縮強度を対象としたものである。

強度論といえば, コンクリートが用い始められてから かなりの期間, その強度がどのようにして決まるかにつ いては，ほとんど経験的な知識しかなかった。しかし， コンクリートが構造物などに広く用いられるようになる につれて,コンクリートの強度発現についての系統的な 研究が活発に行われるよらになり，1920 年前後には, 多 数のコンクリートの強度論が提案された。この間の事情 については, この “やさしいコンクリートの知識（その 9) 配合 (調合)” ${ }^{1)}$ の項に述べられている。コンクリー トの強度論の代表的なものを一括して示すと, 表一1 ${ }^{2) ~ 6) ~}$

* 正会員 名古屋大学教授 工学部建築学科
のよらである。しかし, もともとコンクリートの強度 は, セメント・水・砂・砂利などの品種・品質, それら の混合割合, 練りまぜから打込みに至るまでの施工方法 並びに温・湿度などの環境条件, さらには供試体の形 状・寸法や載荷方法などの試験の条件など, 多くの要因 に左右され, その実態を完全にとらえるのは甚だ困難で あり,コンクリートの強度発現の実態を完全方う簡潔に 説明することは不可能に近い。表一1に示したそれぞれ の強度に関する仮説も, コンクリートの強度についての 一つの側面を説明しうるにすぎない。ただ，コンクリー 卜を製造する側の立場から見た場合, 表一1に示した各 種の強度論の中で, 水セメント比説並びにセメント水比 説が最も実用に供し易い強度仮説であるということはで きよう。

水セメント比説(4)の内容は, 表一1 に示した通りであ るが,これは図一1 に示すような実験事実に基づくもの である。いま，セメントと骨材の混合割合を同じにし て，セメントに対する水の使用量だけを変えてコンクリ 一トを製造すると，打よそ図一1の中の曲線 $a$ のような 結果が得られる。つまりコンクリートの圧縮強度は, 水 とセメントの比率すなわち水セメント比が小さくなるほ ど増大するが, 水セメント比が一定限度以下になると, コンクリートは練りまぜが困難になり, いわゆるパサパ サのコンクリートとなって, 強度はかえって低下寸る。

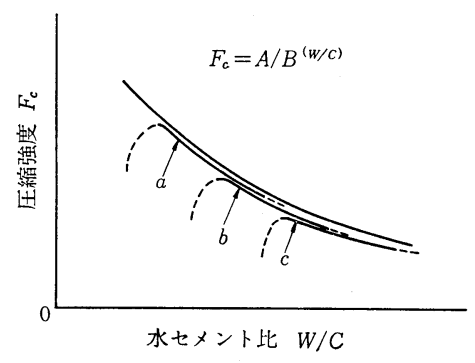

图一1水セメント比と圧縮強度 
表一1 コンクリートの強度論

\begin{tabular}{|c|c|c|}
\hline 称 & 発表者·発表年 & 内 容その他 \\
\hline 最大密度説 ${ }^{2)}$ & $\begin{array}{c}\text { Taylor } \\
\text { Thompson } \\
\text { (1917) }\end{array}$ & $\begin{array}{l}\text { “コンクリートの強度はその密度 } \\
\text { の関数である” } \\
\text { ントペーストの強度, セメントペ } \\
\text { ーストと骨材の付着強度について } \\
\text { 配慮されていない点に問題があ } \\
\text { る。 }\end{array}$ \\
\hline $\begin{array}{l}\text { 骨材表面積 } \\
\text { 説 }\end{array}$ & $\begin{array}{c}\text { Edwards } \\
\text { (1918) }\end{array}$ & $\begin{array}{l}\text { “コンクリートの強度は, 骨材表 } \\
\text { 面積に対するセメントの重量によ } \\
\text { って決まり, コンクリートのワー } \\
\text { カビリチーを満たすための水量は } \\
\text { セメント量ならびに骨材表面積の } \\
\text { 関数である” とするもの。最大密 } \\
\text { 度説と比べ, 水量の考え方をとり } \\
\text { 入れた点が優れている。 }\end{array}$ \\
\hline $\begin{array}{l}\text { 水セメント } \\
\text { 比説 }\end{array}$ & $\begin{array}{c}\text { Abrams } \\
(1918)\end{array}$ & $\begin{array}{l}\text { “セメント品質が同じ場合, コン } \\
\text { クリートがプラスチックでワーカ } \\
\text { ブルならば, その圧縮強度 } F_{c} \text { は } \\
\text { 水セメント比 } W / C \text { にって決ま } \\
\text { る”とするもの。適用範囲に限度 } \\
\text { があるが, コンクリートの配合 } \\
\text { (調合)設計に用いるのに便利であ } \\
\text { る。 } \\
\end{array}$ \\
\hline $\begin{array}{l}\text { セメント水 } \\
\text { 比説 }\end{array}$ & $\begin{array}{l}\text { Lyse } \\
(1925)\end{array}$ & $\begin{array}{l}\text { “水セメント比の代りにセメント } \\
\text { 水比 } C / W \text { を用いると, コンクリ } \\
\text { 一トの压縮強度 } F_{c} \text { とセメント水 } \\
\text { 比 } C / W \text { 法のような線形式で表 } \\
\text { わすことができる } \\
\quad F_{c}=A(C / W)+B \\
\text { ただし, } A, B: \text { 実験定数 } \\
\text { とするもの。水セメント比説より } \\
\text { コンクリートの配合設計に用いる } \\
\text { のにさらに便利である。 }\end{array}$ \\
\hline $\begin{array}{l}\text { セメント空 } \\
\text { げき比説6) }\end{array}$ & $\begin{array}{l}\text { Talbot } \\
\text { (1921) }\end{array}$ & $\begin{array}{l}\text { “有効水量*を 用いたコンクリー } \\
\text { 卜の圧縮強度 } F_{c} \text { と空げきセメン } \\
\text { 卜比 }(v / c) \text { との間には, 次のよう } \\
\text { な関係, } \\
\qquad F_{c}=\frac{2250}{(1+v / c)^{0,28}} \\
\text { がなりたつとするもの。水セメン } \\
\text { ト比説やセメント水比説が適用で } \\
\text { きないパサパサコンクリートなど } \\
\text { にも適用できる。調合 (配合) 設 } \\
\text { 計に適用するには工夫が必要。 } \\
\text { * 有効水量 : 粗骨材の空げきを } \\
\text { 満たし, その表面をおおうの } \\
\text { に十分で, かつそのモルタル } \\
\text { が最小重量となるような水量 } \\
\text { のこと。 }\end{array}$ \\
\hline
\end{tabular}

実用的な見地から，このようなパサパサのコンクリー ト，ならびに水セメント比が極端に多いコンクリートを 除外すれば, コンクリート強度と水セメント比の関係 は, 図一1 の中の曲線 $a$ のらちの実線部分のようにな
り, 強度は水セメント比の減少と共に増大寸ることにな る。セメントと骨材の量を変えて同様の実験を行い, 図一1 に示寸ように曲線 $b, c$ などを求め, これらの曲線 の実用部分を一括すると, 図一1 中の太い実線で示すよ らな曲線, つまり水セメント比説のいらところの圧縮強 度と水セメント比との関係が得られる。この場合の両者 の関傒は，次式のように表すことができる。

$$
\begin{gathered}
F_{c}=\frac{A}{B^{(W / C)}} \\
\text { こに, } \quad F_{c}: \text { 圧縮強度 } \\
W / C: \text { 水セメント比 } \\
A, B: \text { 実験定数 }
\end{gathered}
$$

セメント水比 説) は，さきの水 セメント比の代り に，その逆数のセ メント水比を用い ると,コンクリー 卜強度とセメント 水比との関係は, 実用のコンクリー 卜の範囲では,

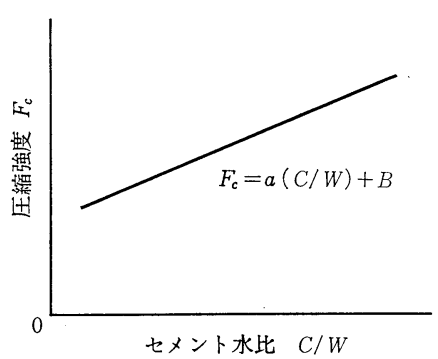

図一2 セメント水比と圧縮強度
図一2 に示すような直線で示すことができるとするもの である。この場合, コンクリートの強度とセメント水比 との関係は, 次式のように表すことができる。

$$
F_{c}=a(C / W)+b
$$

ここに, $F_{c}$ : 圧縮強度 $C / W:$ セメント水比

$$
a, b: \text { 実験定数 }
$$

コンクリートの調合 (配合) 設計の際, 式 (1)のよう な指数式を用いるよりも，式 (2)のような直線式を用い る方が便利であることは, 式 (1) と式 (2) あるいは図 -1 と図一2 を比べると, 直ちに理解できよう。

水セメント比説や, セメント水比説などの強度仮説が ぞのような根拠によるものであるかの詳細については， この教室の “やさしいコンクリートの知識（その 4) セ メントの製造と性質 (2)” 江述べられているので参照 されたい。一般にセメントの水和に必要な水量は, セメ ント重量の約 $30 \%$ 前後であるといわれている。コンク リートの練りまぜの際には骨材も使用されているから， これより多い水量を用いなければ，作業性のよいコンク リートを得ることができない。通常, セメント重量の 40 70\% の水が用いられる。その場合，セメントの水 和に必要な水以外は余剩水となって, 一部はコンクリー トの表面に浮上り，一部はセメントペーストの中や，骨 材の下部に水げきとなって残る。このよらにして, 硬化 後のコンクリート中に残された水げきは, コンクリート 
の構造欠陥, つまりコンクリート内部の弱点となって, 荷重を受けたとき破壊のきっかけとなる。この構造欠陌 の量は, 水セメント比の大きいコンクリートほど多く, したがってその強度も低下する。

このような考え方 は，普通コンクリー トのように, 骨材強 度がセメントペース 卜強度よりも大きい 場合には成立する が，軽量骨材コンク リートのように，と きには骨材強度がセ メントペーストの強 度を下回る場合には あてはまらなくな

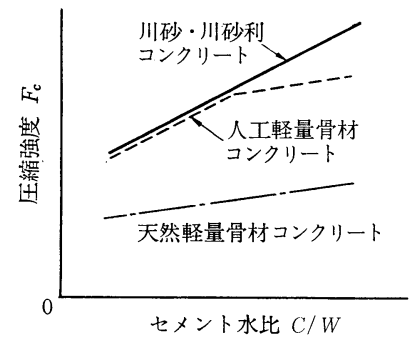

図一3各種骨材を用いたコンク リートのセメント水比と 圧縮強度（村田二郎によ る)
る。事実, 軽量骨材コンクリートの場合, 骨材自身の破 壊がセメントペースト部分の破壊より先に起こり，これ が引きがねになってコンクリートの全体崩壊をもたらす ものもあり, この場合, 水セメント比を小さくしても, コンクリート強度はそれほど増大しない。図一3 はその 一例を示す。

すでに述べたように, 水セメント比説やセメント水比 説は, ワーカブルでないコンクリートには当てはまらな い。例えば，パサパサのコンクリートのような場合に は,むしろ空げき説による方が, コンクリートの強度発 現の現象をよく説明できるとされている。

\section{2. 圧縮時のコンクリートの壞れ方}

圧縮試験を行った コンクリートの壊れ 方を見ると, 普通二 ンクリートの場合, 図一4に示すように コンクリートの打込 み方向を矢印のよう にした場合，破断が 骨材の下面に起こ。 ていることに気つかか れた方も多いと思 ら。これはさきに述

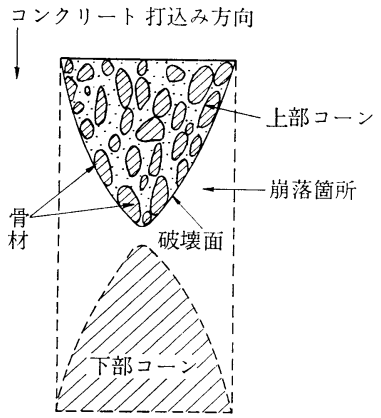

図一4 普通コンクリートの 圧縮破断面
べたように，コンクリートの練りまぜの際の余剩水が, 骨材下面に残ってコンクリート内部の構造欠陷となった ためである。この現象は, 水量の多いコンクリートや, 打込み時の締固め作業の不十分なコンクリートによく見 られる。
圧縮供試体の壊

れ方をみて, 今一 つ気づくことがあ る。多くの場合, 圧縮破壞した供試 体は，全体が同時 に壊れるのではな くて，まず局部的

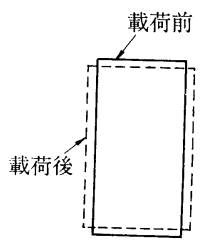

(a) 摩擦のないとき
な破壊が供試体高さの中程から始まり，最終的には前掲 の図一4 に示すように供試体上・下部に円錐状（角柱供 試体の場合は角錐状）の部分が残って，残余の部分が細 かく壊れてしまう。これは，供試体と圧縮試験機の金属 製加圧板との間に働く摩擦のために起こる現象である。 供試体と加圧板との間に摩擦がない場合には，供試体は 図一5（a）に示すように, 加力方向に縮み, 加力と直交 する方向に均等にふくらんで, 供試体は全体的に崩壊す る。ところが，加圧板と供試体の間に摩擦がある場合に は，供試体は載荷板近くでは，水平方向のふくらみを拘 束され, 図一5（b）に示すように, ビア樽型の変形をし て壊れ，このとき先に示した図一4のような破壊形態を 示す。

圧縮供試体がこ $\square^{P}$ のような壊れ方を 寸るときには，実 は供試体の載荷面 での応力分布は一 様ではなく，図一 6 に示すように中 央部でやや大きく なる山形の分布を 示している。供試 体のせいが高い場 合には，供試体の 高さの中程で, 図一6にも示すように圧 縮応力分布はほぼ均等に なるが，せいの低い供試 体では, 圧縮応力分布の 不均等は供試体全域に及 ぶ。このため圧縮供試体 の強度は, 供試体の高さ $H$ と直径 $D$ の比 $H / D$ によって異なり, 図一7 に示すように $H / D$ が小 さいほど, 大きい圧縮強 度を示すことになる。た だし，図一7にも見られ

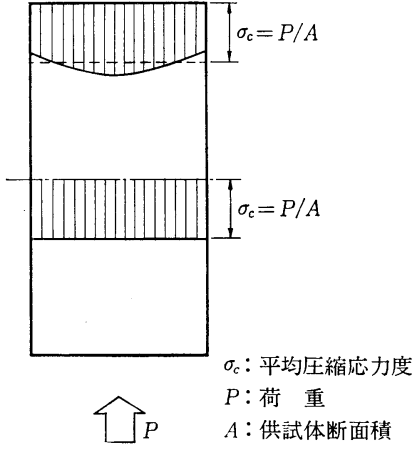

図一6 圧縮供試体の応力分布

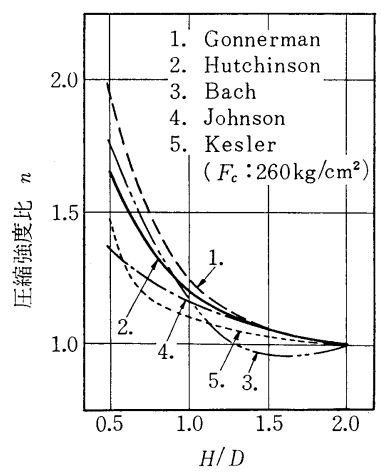

図-7 供試体の高さ $\boldsymbol{H}$ と直径 $\boldsymbol{D}$ の比と圧縮強度との関係 (その 1) 
るように $H / D$ と圧縮強度との関係は, 実験条件の違い などもあって, 研究者によってかなり異なった様子を示 している。

$H / D$ によるこのよう な圧縮強度の変化をなく するためには, 載荷板と 供試体間の摩擦を無くす ればよい。筆者らは載荷 板と供試体の間に，金属 䇴にシリコングリースを 塗った減摩用のパットを 狭んで摩擦を小さくして 圧縮試験を行い ${ }^{8)}$, 図一 8 に示すように, H/D による強度変化が少なく なるという結果を得てい

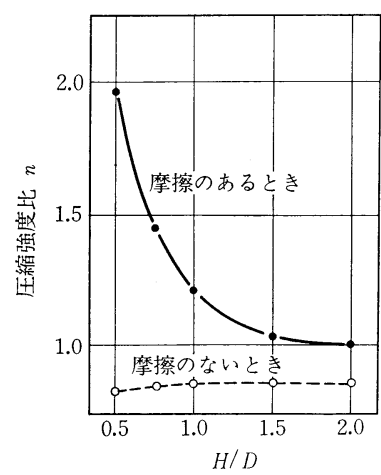

図一8 供試体の高さ $\boldsymbol{H}$ と直径 $D$ の比と圧縮強度との関係 (その 2)
る。真の圧縮強度は, 加圧面に摩擦のない場合の強度と すべきであるが, 加圧面の摩擦を減じたとき, 供試体の 製作精度や加圧装置の精度をよほど良くしないと, 加圧 と同時に供試体は側方に滑り出し, 試験が非常に困難に なる。一方,従来からの試験方法は実用的ではあるが, 得 られた強度が必ずしも, 真の圧縮強度を示していないこ とに十分留意する必要がある。な拉, 図一8 からわかる ように, 加圧面に摩擦のある場合は, $H / D$ の大きい供 試体の方が真の圧縮強度に近い值を示すものと考えら れ，この意味でョーロッパで用いられている正立方体の 供試体よりもわが国やアメリカで用いられている $H / D$ $=2.0$ の円柱形供試体の方が, 真の圧縮強度に近い強 度を示す。ちなみに, 同品質のコンクリートを用いた場 合, 正立方体供試体の圧縮強度は, $H / D=2.0$ の円柱形 供試体の圧縮強度より大きく，その比率はおよそ 1.25 の程度であるといわれている。

\section{3. 引張強度と曲げ強度}

はじめにも述べたように, コンクリートの場合, 圧縮 強度に比べると, 引張強度や曲げ強度ははるかに小さく その比率はおよそ表一2 に示すようである。引張強度や 曲げ強度は, すでに求められているこれらの強度と圧縮 強度との相関関係を用いて, 圧縮強度から推定すること もできるが, 試験を行ってこれらの強度を直接求めた方

表一2 コンクリートの引張り及び曲げ強度と 圧縮強度の比

\begin{tabular}{l|c|c}
\hline コンクリートの種類 & 引張強度/圧縮強度 & 曲げ強度/圧縮強度 \\
\hline 普通コンクリート & $1 / 9 \sim 1 / 13$ & $1 / 5 \sim 1 / 7$ \\
人工軽量骨材コンク & $1 / 9 \sim 1 / 15$ & $1 / 6 \sim 1 / 10$ \\
リート & & \\
\hline
\end{tabular}
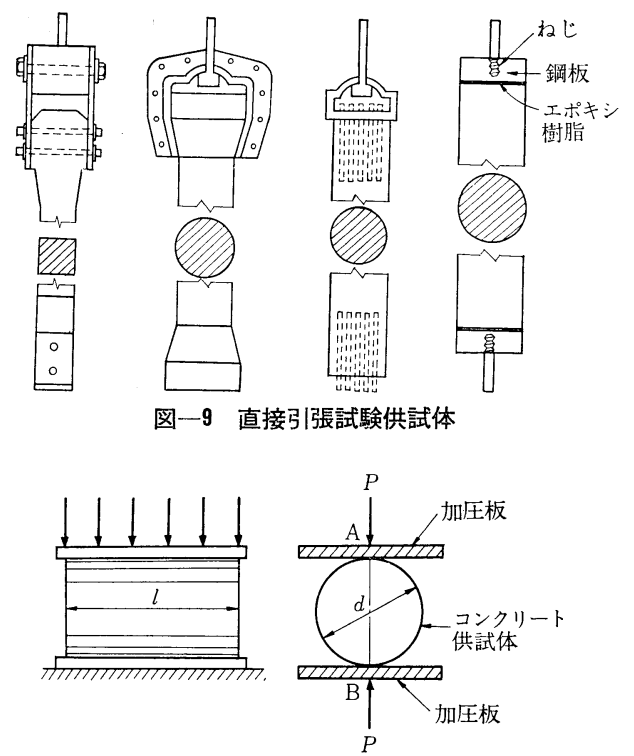

図-10 割裂試験供試体

がより確実な資料が得られる。

コンクリートの引張強度を求めるには, 図一9に示す ような直接引張りの方法と, 図一10 に示すような割裂 引張りの試験方法とがある。直接引張りの方法は, コン クリートの引張強度を求める直截な方法として分り易い が, 何しろコンクリートは, 引張りや曲げに弱い材料で あるため, 純引張りによる破壊をおこすためには, 供試 体の形状・寸法や加力方法に格別の配慮が必要である。 図一9 の供試体はいずれもその工夫のあとがみられる。 これに比べると割裂法 (Split method) は, 試験の方法は 圧縮試験同様，極めて簡単である。すなおち円柱形供試 体をねかして, 図一10に示すように直径方向に加圧し， これが 2 つに破断したときの荷重から，次式によって引 張強度を求めればよい。

$$
\sigma_{t}=2 P / \pi \cdot d \cdot l
$$

$$
\begin{gathered}
\text { ここに, } \sigma_{t}: \text { 割裂引張強度 } \\
P: \text { 破断荷重 }
\end{gathered}
$$

$$
d, l: \text { それぞれ供試体の直径及び長さ }
$$

JIS に定められた引張試験方法は, この割裂法であっ て, 実用的に十分満足すべき引張強度が得られるとされ ている。

曲げ強度を求める方法としては, 図一11 に示す一点 載荷の方法と二点載荷（三等分点載荷ともいら）の方法 とがある。日本の規格 (JIS) は二点載荷法を採用してお りアメリカの規格 (ASTM) では一点載荷法を採用して いる。これらの場合, 破壊時の最大曲げモーメント $M$ は, 図一11に示したよらに求めることができる。曲げ載 荷時の破壊は, 最大曲げモーメント作用域の供試体最下 部の引張ひびわれをきっかけとして生ずる。供試体破断 


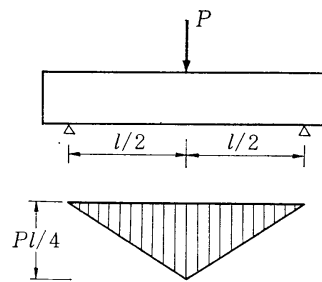

曲げモーメント $M$

(a) 一点載荷

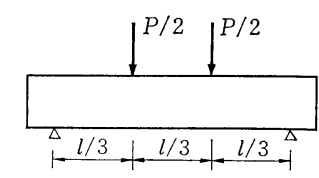

$P l / 6]$

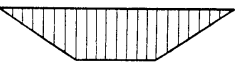

曲げモーメント $M$

(b) 二点載荷
図一11曲げ試験方法
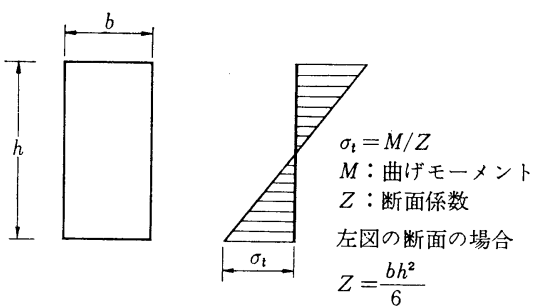

図一12曲げ応力分布

部の応力分布を, 図一12 のように仮定すれば, 曲げ破 壊時の最大引張応力度すなわち曲げ強度は次式によって 求めることができる。

$$
\sigma_{b}=M / Z
$$

$$
\text { ここに, } \sigma_{b}: \text { 曲げ強度 }
$$

$M:$ 破壊曲げモーメント

$Z$ : 断面係数, 幅 $b$, 高さ $h$ の長方形断面材 の場合 $Z=b h^{2} / 6$

つまり, 曲げ強度とは, 曲げ破壊時のコンクリートの 引張縁の引張強度にほかならない。にもかかわらず, 前 揭の表一2.にも示したように, 曲げ強度は, 引張強度よ りも大きい值を示すことが知られている。さらにまた不 都合なことに, コンクリートの曲げ強度は, 供試体の形 状・寸法や載荷方法によっても異なり，たとえば一点載 荷と二点載荷とでは, 同品質のコンクリートであっても その曲げ強度は異なり, 図一13 に示すように, 二点載 荷の場合より一点載荷の場合の方が大きい曲げ強度を示 すことが知られている。

このように，同じ引張りによる破壊であり乍ら，その

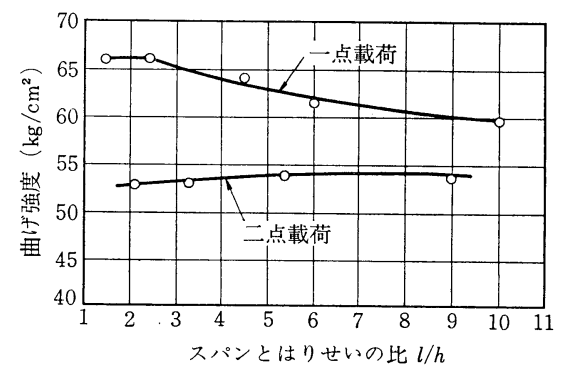

図一13一点載荷時と二点載荷時の曲げ強度（日本建築 学会建築材料用教材, 昭和 42 年版より)
最大応力度が, 割裂試験と曲げ試験, あるいは同じ曲げ 試験でも一点載荷と二点載荷とで違うのは, 供試体内部 の応力分布の違いによるものであるとする説がある9。 コンクリートやモルタルのように，圧縮よりも引張りに 弱い材料の場合, 引張破壞はその材料組織の中の最弱の 箅所から始まるが，破壊につながるひびわれは，高応力 体積 (Highly Stressed Volume) として定義される領域 が大きい供試体の方が破壊し易く, みかけの強度が小さ くなるといら仮説である。ここに, 高応力体積といらの は, その材料の純引張強度を $\sigma_{b}$ とするとき, 供試体内 部で $0.85 \sigma_{b}$ 以上の応力を示す体積をいう。たとえば, 図一11（a) 亿示すような一点載荷のコンクリート曲げ供 試体の場合, 高応力体積は $b h L / 1600$ となり, 図一11 （b）に示す二点載荷曲げ試験体の高応力体積は $7 \mathrm{bhL} /$ 800 となる。

この仮説によって $\phi 15 \times 30 \mathrm{~cm}$ の円柱形割裂試験用供 試体, 及び断面 $15 \times 15 \mathrm{~cm}$, スパン $45 \mathrm{~cm}$ の曲げ試験用 供試体に一点載荷をした場合と二点載荷をした場合の高 忘力体積, 並びに破壞強度の比を求めてみると, 図一14 に示すようになる。これによって前掲の表一2 及び図一 13 に示した引張試験強度 と曲代試験強度の差, あるい は一点載荷時の曲げ強度と二点載荷時の曲げ強度の違い の現象の説明をある程度はすることができる。

\begin{tabular}{c|c|c|c}
\hline 断面及び載荷方法 (単位 $: \mathrm{cm})$ & $\begin{array}{c}\text { 高応力体積 } \\
V\left(\mathrm{~cm}^{3}\right)\end{array}$ & $\begin{array}{c}\text { 強度比率 } \\
n\end{array}$ \\
\hline & 6.3 & 1.48 \\
\hline
\end{tabular}

\section{図一14 各種供試体の高応力体積 $V$ と強度比率}

4. 強度試験結果のばらつきについて

同種のコンクリートの強度試験を, 全く同じ方法で行 っても, 測定結果はある程度のばらつきを示すのはごく 普通のことである。このような強度試験結果のばらつき はおよそ次のような原因によるものと考えられる。

コンクリートの製造に関するもの：セメント，骨材な

ど使用材料の品質のばらつき, 計量誤差, 練りまぜ 作業の不備など

供試体採取に至るまでの取扱いに関するもの：不適切 
な運搬時間，不適切な打込み作業など

供試体の製作に関するもの：型わくの不備, キャッピ

ングの不良, 養生方法の不備など

試験方法に関するもの：試験機への供試体設置方法の

不備, 不適切な載荷速度など

強度試験に際しては, これらの諸事項に十分注意し, 測定值のばらつきを極力少なくするよう留意しなければ ならない。

\section{5. 弾性係数について}

構造材料としての コンクリートは, 強 度だけではなく変形 性能もまた重要な要 素である。材料の変 形性能を評価する物 理量の一つに, この “やさしいコンクリ 一トの知識（その 13）コンクリートと 力(1)”(10)にも述べら

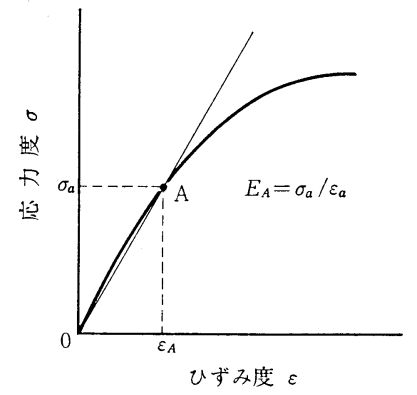

図-15 弾性係数（割線係数） の求め方
れている弾性倸数がある。構造設計に用いるコンクリー トの弾性係数には, 通常図一15 に示す強度の $1 / 3 \sim 1 / 4$ 点における割線係数を用いる。この值が大きいコンクリ 一トほど, 同じ応力を加えたときの変形量が小さいこと を意味する。

コンクリートの弾性係数は, コンクリートの材質や強 度の影響を強くうける。これは, 鉄や鋼の場合, その弾 性係数は，材質や強度特性にかかわらず，ほぼ $2.1 \times$ $10^{6} \mathrm{~kg} / \mathrm{cm}^{2}$ と一定の值を示すのに比べ，特徵的である。 図一16 は各種コンクリートの強度の $1 / 3$ 点の割線係数 と圧縮強度との関係を示したもので, 同種コンクリート では圧縮強度の大きいほど弾性係数が大きく，また同じ 強度のコンクリートでは, 普通コンクリートよりも軽量 のコンクリートの方が弹性係数が小さい值を示すことが

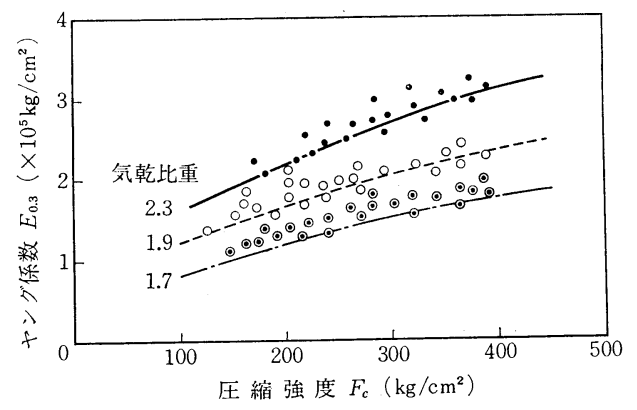

図一16 各種コンクリートの弾性係数 $E_{0.8}$ と 圧縮強度 $\boldsymbol{F}_{\boldsymbol{c}}$ との関係

分かる。

コンクリートの弾性係数が，このように使用骨材によ って異なる現象を説明するのに，複合材モデルを用いる 方法がある。すなわち、コンクリートはセメントペース トと骨材とからなる複合材料であると考えると，このよ らな複合材の変形性質は, それを構成する素材, つまり セメントペーストと骨材の変形特性ならびに容積比率に よって左右される。

いま，コンクリート中の骨材及びセメントペーストの 占める容積比率をそれぞれ $V_{a}$ 及び $V_{p}$, 骨材及びセメ ントペーストの弾性係数をそれぞれ $E_{a}$ 及び $E_{p}$ とする。 簡単のためこれらの構成素材を図一17 (a)のよらにとり まとめてしまうと，このような材料を上下から均一に圧 縮したときの弾性係数 $E_{c}$ は次のように表すことができ る。

$$
E_{c}=E_{a} V_{a}+E_{p} V_{p}
$$

また，骨材及びセメントペーストを，図一17(b)のよ うにとりまとめてみると，このような材料を上下から一 定応力で圧縮したときの弾性係数 $E_{c}$ 注次のように表す ことができる。

$$
1 / E_{c}=V_{a} / E_{a}+V_{p} / E_{p}
$$

これらの関係を図示すると, 図一18 の直線（a）及び 曲線 (b)のようになる。骨材とセメントペーストとの構 成は, 図-17の（a) でもなく（b）でもない。図一17 (e) のように，セメントペースト中に骨材がランダムに 配置したモデルを用いると，実情に近くなるが，そのよ らな材料の弾性倸数を数式表示するのは容易ではない。

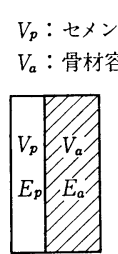

(a)
$E_{p}:$ セメントペースト弾性係数 $E_{a}:$ 骨材弾性係数

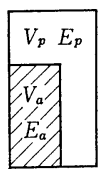

(c)

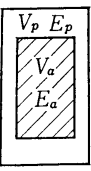

(d)

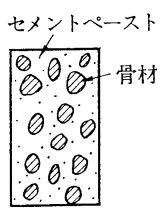

(e)
図一17 各種のコンクリートモデル

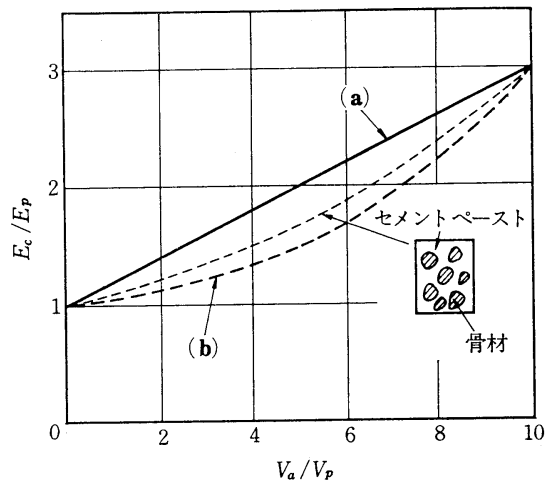

図一18 各種のモテルコンクリートの弾性係数 
そのため, その途中段階として, 図一17の (c), (d)の ような各種のモデルが提案され検討が行われている(1)。 なお，コンクリートを，骨材とセメントペーストからな る二相材と考えた場合, その弾性係数は図一18 に示す ように図一17(a)のようなモデルがその上界值を，図一 17 (b) のモデルが下界值を示し, 実際のコンクリートの 弾性係数は, その中閒の曲線で表されるともいわれてい $る^{11)}$ 。

さきにのべた, 軽量コンクリートの弾性係数が, 普通 コンクリートの弾性係数に比べて小さい值を示すのは, 骨材の弾性係数が軽量骨材の方が小さいためである。こ のことは以上の説明で理解できる。なお, 同時にまた, 弾性係数の大きい軽量骨材がもし開発されたとすれば, それを用いたコンクリートは, 軽量であっても弾性係数 の大きいものになることも理解する必要があろう。

\section{引用文献}

1) 長滝, 中山, 白山： “やさしいコンクリートの知識（その 9) 配合 (調合)”, コンクリート工学, Vol. 16, No. 12, Dec. 1978

2) Taylor, Thompson : "Plain and Reinforced Concrete" 1917

3) L.N. Edwards : "Proportioning the materials of mortars and concretes by surface areas of the aggregates" Proc. ASTM, Vol. 18, 1918
4) D.A. Abrams : "Design of concrete mixture" Structural Materials Research Lab., Lewis Institute, Bul. 1, Chicago, 1918

5) I. Lyse : "Tests on consistency and strength of concrete having constant water content" Proc. ASTM, Vol. 32, Part II, 1925

6) A.N. Talbot: "A proposed method of estimating the density and strength of concrete and of proportioning the materials by the experimental and analytical consideration of voids in mortar and concrete" Proc. ASTM, 1921

7）森：“やさしいコンクリートの知識（その 4) セメントの 製造と性質 (2)” コンクリート工学 Vol. 16, No. 7, July 1978

8）小阪, 谷川：“各種骨材コンクリートの圧縮強度におよぼ す試験体寸法と載荷面の摩擦の影響について” セメント コンクリート No. 265 March 1969

9) R.J. Torrent : "A general relation between tensile strength and specimen geometry for concrete-like materials" Materials and Structures Research and Testing Vol. 10, No. 58, 1977

10）岡島: “やさしいコンクリートの知識（その 13）コンクリ ートと力 (1)” コンクリート工学 Vol. 17, No. 4, April 1979

11) P. Dantu : "Etude des contraintes dans les milieux hétérogénes. Application au beton" Annales de l'Institut Technique du Bátiment et des Travaux Publics. Vol. 11, No. 121, January 1958 